\title{
EXEMPTIONS FROM A TENANT'S EXPRESS OBLIGATION TO REPAIR - IS THE LANDLORD RESPONSIBLE BY IMPLICATION?
}

\author{
William Duncan*and Sharon Christensen**
}

[The Victorian Supreme Court in Carbure Pty Ltd v Brile Pty Ltd (2002) V Conv R 54-663 declined to imply a covenant on the part of the landlord to undertake structural repairs to leased premises where the express repair covenant in the lease excluded from the tenant's obligations structural repair. By contrast, the court in Reilly $v$ Liangis Investments (2000) 9 BPR 17,509 (NSWSC) assumed that in identical circumstances, the landlord had the responsibility to undertake structural repairs. The conclusion that neither a landlord nor a tenant is obliged to undertake repair falling within the exclusions in the lessee's covenant also has ramifications for other excluded obligations such as fair wear and tear. This article examines the position of the parties in this anomalous situation and whether or not an implied term relating to structural repair could exist against the landlord. The article critiques the differing views in relation to the landlord's obligation of repair for stand alone leased premises as compared to multi-tenanted buildings and the background influence of the covenant for quiet enjoyment. It concludes by noting that a repair covenant will rarely be implied against a landlord to the benefit of a tenant and, for the sake of certainty, if possible, an express covenant on the part of the landlord to undertake structural repair should be incorporated in the lease.]

\footnotetext{
* Professor, Queensland University of Technology and Consultant, Allens Arthur Robinson Solicitors. ** Gadens Professor of Property Law, Queensland University of Technology and Consultant Gadens Lawyers.
} 


\section{CONTEXT}

The decision of Carbure Pty Ltd v Brile Pty Ltd ${ }^{1}$ marks an appropriate occasion to revisit the issue of implied terms for repair in commercial leases. The decision highlights the anomalous ways in which tenants' express covenants to repair with enumerated exceptions, but principally the exception of structural repair, are construed where there is no express covenant on the part of the landlord to repair. The problem arises particularly in the instance of the lease of a stand alone building as opposed to a lease of a multi-tenanted building. Whilst one construction favours no obligation to repair implied against a landlord, another judicial school seems to assume that the landlord would be responsible for structural repair where the lease exempts the tenant from this obligation. This article questions the validity of each of these divergent views in light of the judicially accepted approaches to construction of repair covenants and the ambit of the covenant for quiet enjoyment. First, however, it is appropriate to examine the anatomy of a common commercial lease and the relationship between express and implied terms.

\section{ANATOMY OF A COMMERCIAL LEASE}

Whilst there is no standard commercial lease, it could be said that generally, commercial leases contain three types of clauses. First, there are the most numerous clauses, those embodying the obligations of the tenant, the second most numerous being those embodying mutual obligations on the part of the landlord and tenant respectively and the third being those obligations to be observed by the landlord. In truth, many of the landlord's obligations will remain unexpressed and it will be a matter for the court, upon a reasonable construction of the lease, to determine whether there are any implied terms which the landlord should observe. In the field of landlord and tenant, particularly where commercial leases give lengthy expression to the intention of the parties, implied terms against the landlord have traditionally been treated with caution. Perhaps the most common application of implied terms against a landlord is those implied by law, such as the covenants to give the tenant quiet enjoyment and not to derogate from the grant. ${ }^{2}$ It is accepted that if those covenants were not express, they would be implied at law by reason of the existence of the relationship of landlord and tenant. ${ }^{3}$ More recently, there have been suggestions that there may be circumstances where an implied term of good faith on

\footnotetext{
1 (2002) V Con R 54-663.

2 Essentially, such a covenant is one on the part of the landlord that the landlord will not interfere with the enjoyment by the tenant of the benefits of the lease.

${ }^{3}$ Markham v Paget [1908] 1 Ch 697; Browne v Flower [1911] 1 Ch 219, 225-6 (Parker J).
} 
the part of the landlord may be imported into commercial leases giving expression to principles formulated originally in construction contracts. ${ }^{4}$ However, where the implication of such a term of good faith has been argued in respect of a commercial lease, ${ }^{5}$ the court has generally failed to imply a term. Furthermore, there is considerable argument as to whether a term of good faith may be incorporated by implication in the normal way, that is as suggested in BP Refinery (Western Port) Pty Ltd $v$ Hastings Shire Council ${ }^{6}$ or whether the principle should be used as a canon of construction in any particular lease. ${ }^{7}$ Literature on this subject is generally inconclusive. $^{8}$

Whilst there is ample evidence of terms being implied in leases against the landlord, particularly in relation to the obligation to give quiet enjoyment and not to derogate from the grant, more recently several tenants have sought to imply an obligation on the part of the landlord to repair structural defects in a commercial building. It is fair to say that the assertion of such an implied term has generally not been received well by the courts either in Australia or in England.

\section{The Primary Rules for Construing Repair Covenants}

Before looking at whether a landlord's obligation to repair can be implied, it is appropriate to note several relevant canons of construction utilised by the courts when considering repair covenants in leases. First, putting aside statutory provisions which might be implied, it is clear that in the absence of any express covenant to repair in the lease itself, neither landlord nor tenant would bear any obligation to

\footnotetext{
4 Renard Constructions (ME) Pty Ltd v Minister for Public Works (1992) 26 NSWLR 234; Hughes Aircraft Systems International v Air Services Australia (1997) 76 FCR 151.

5 For example Alcatel Australia Ltd v Scarcella (1998) 44 NSWLR 349; Advance Fitness Corporation Pty Ltd v Bondi Diggers Memorial Sporting Club Ltd [1999] NSWSC 264. In Softplay Pty Ltd v Perpetual Trustees (WA) Pty Ltd [2002] NSWSC 1059, Barrett J extended an interim injunction at the urging of a tenant plaintiff upon the grounds that the balance of convenience favoured that course, and that there was a serious issue to be tried in circumstances where the tenant was attempting to prevent the landlord establishing a competing business in the same shopping centre. The landlord had proposed to make available child minding services on a no charge basis in direct competition with the tenant who was charging for the service. The tenant raised the issue of the implication of a term requiring the exercise of good faith by the landlord. Barrett J said that there was a 'cogent argument' that such a term might be implied in this case ([9]).

${ }^{6}$ (1977) 180 CLR 266.

7 See Elizabeth Peden, 'Incorporating Terms of Good Faith in Contract Law in Australia' (2001) 23 Sydney Law Review 222.

8 See Rachael Mulheron, 'Good Faith in Commercial Leases: New Opportunities for the Tenant' (1996) 4 Australian Property Law Journal 223; Michael Redfern, 'Implied Duty of Good Faith' (1999) 7 Australian Property Law Journal 179; Eileen Webb, 'Break Clauses, Self Interest and Notions of Good Faith' (2000) 8 Australian Property Law Journal 175; Eileen Webb, 'The Scope of the Implied Duty of Good Faith - Lessons from Commercial and Retail Leasing Cases' (2001) 9 Australian Property Law Journal 1; W D Duncan, 'The Implication of a Term of Good Faith in Commercial Leases' (2002) 9 Australian Property Law Journal 209.
} 
undertake repair. ${ }^{9}$ It is therefore, theoretically possible for premises to fall into and remain in disrepair without any obligation on either party to take any action. In some jurisdictions the omission of an express covenant on the part of the tenant to repair is dealt with by an implied covenant imposed by statute. ${ }^{10}$ However, such a covenant implied by statute on behalf of the tenant to keep the premises in good and tenantable repair normally exempts damage from natural elements such as fire, flood, lightning, storm and tempest and, generally, fair wear and tear. Often, the covenant exempts repairs of a structural nature. Except for the fair wear and tear and structural repair exceptions all other exceptions are matters against which a landlord and/or a tenant would usually carry insurance.

Secondly, it is critical to ascertain the respective obligations of landlord and tenant in relation to the actual subject matter and thus the responsibility of that party to repair. This depends very much on the construction of the individual lease. ${ }^{11}$

Thirdly, there have been judicial limitations placed upon the interpretation of all covenants to repair on the part of the tenant. An obligation to repair premises does not import an obligation to replace them completely although repair may involve some renewal or replacement. ${ }^{12}$ It is a question of degree whether the work falls within the ambit of an obligation to repair or outside the scope of the covenant. ${ }^{13}$ Further, structural repairs may often be required because of an inherent defect in construction. Again, the repair of an inherent defect has been said, in dicta, to be beyond the scope of any obligation contained in the covenant to repair on the tenant's part. ${ }^{14}$ This would have particular application to leases of stand alone premises. In Weatherhead v Deka New Zealand Ltd, ${ }^{15}$ the New Zealand Supreme Court was required to interpret a standard covenant to repair in the lease of a stand alone warehouse constructed in 1914 incorporating a restaurant property. The court indicated that 'inherent defects in the building at the commencement of the lease, the structural character of the work required and the nature and extent of the work to remedy those defects' took the obligation to do so out of the covenant to repair of the tenant. ${ }^{16}$ However, in this case, the premises were virtually unusable for want of serious repairs.

\footnotetext{
${ }^{9}$ Ayling $v$ Wade [1961] 2 QB 228, 234 (Danckwerts LJ); Warren v Keen [1953] 3 WLR 702, 704-5 Australis Media Holdings Pty Ltd v Telstra Corporation Ltd (1998) 43 NSWLR 104, 125 (CA) ('in the absence of an express covenant, a landlord is not bound in contract to repair demised premises').

${ }^{10}$ Conveyancing Act 1919 (NSW) s 84(1)(b); Transfer of Land Act 1958 (Vic) s 67(1)(b); Property Law Act (Qld) s 105(1)(b); Transfer of Land Act 1893 (WA) s 92(ii), Land Titles Act 1925 (ACT) s 119(b).

${ }^{11}$ For an example of the importance of construing the lease in question, see Combara Nominees Pty Ltd v McIllwraith Davey Pty Ltd (1991) 6 WAR 408, 410, 415-6; Batiste v Lennin (2002) 11 BPR 20 (on a construction of the lease the lessee had the obligation for structural repair).

${ }^{12}$ Lurcott $v$ Wakeley \& Wheeler [1911] 1 KB 905, 914, 923-6.

13 Graham v Markets Hotel Pty Ltd (1943) 67 CLR 567, 579 (Latham CJ).

${ }^{14}$ Ibid 581 (Latham CJ) and 595 (Williams J) in deference to the judgment of Jordan CJ in the court below sub nom Graham v Markets Hotel Ltd (1942) 43 SR (NSW) 98, 103; the situation in England with respect to inherent defects is somewhat different, see Ravenseft Properties Ltd $v$ Davstone (Holdings) Pty Ltd [1980] QB 12, 21.

15 [2000] 1 NZLR 23.

16 Ibid 29-30 (the building was fundamentally unsound and could only be repaired by undertaking works costing as much as replacement of the building with a new structure).
} 
Fourthly, there is a principle of long standing in the common law that there is no condition is implied in a lease of real property that the demised premises are fit for the purpose for which they are let. ${ }^{17}$ In espousing this proposition in 1843 , following a complaint by a tenant of a bug infested dwelling house which the tenant claimed was unfit for human habitation, in respect of the practical outcome, Parke B said

It is much better to leave the parties in every case to protect their interest themselves, by proper stipulations, and if they really mean a lease to be void by reason of any unfitness in the subject for the purpose intended, they should express that meaning. ${ }^{18}$

It is, indeed, very common for commercial leases to expressly state that the landlord takes no responsibility in respect of physical fitness for the purpose of any premises let. This rule would apply notwithstanding an express covenant of that nature and the fact that the landlord may be aware of the purpose for which the tenant desires the premises. ${ }^{19}$ Nor does the express stipulation of the use to which the premises may be put give any rise to an implication on the part of the landlord that the premises are suitable for that purpose. ${ }^{20}$

In summary, therefore, given these parameters, covenants to repair on the part of the tenant, qualified or unqualified, must be interpreted, not only within the context of the entire lease, but also taking into account the type of property and the extent and kind of disrepair.

\section{Is the Lessor's Obligation to Repair a QUESTION OF LAW OR FACT?}

As with all contracts, terms may be implied into a lease as a matter of law or fact. The principles applicable are relatively settled. In the first instance terms may be implied at law in certain classes of contract, although those terms may not find specific expression in the contractual statements or documents of the parties. These may take effect despite the terms of the contract. The implied obligations of a landlord to provide quiet enjoyment and not to derogate from the grant are terms implied at law in all leases. ${ }^{21}$ In the second instance, terms may be implied in fact to

\footnotetext{
${ }^{17}$ Hart $v$ Windsor (1843) $12 \mathrm{M} \& \mathrm{~W} 68$.

18 Ibid 87-8.

19 Cruse v Mount [1933] 1Ch 278, 283.

${ }^{20}$ Bradford House Pty Ltd v Leroy Fashion Group Ltd (1983) 68 FLR 1, 8-9.

${ }^{21}$ Budd-Scott v Daniel [1902] 2 KB 351, 356; Browne v Flower [1911] 1 Ch 219; applied in Kazas \& Associates Pty Ltd v Multiplex (Mountain Street) Pty Ltd [2002] NSWSC 840.
} 
give effect to the presumed intention of the parties. Whilst there are several categories of term implied in fact, the most relevant to the question of repair under leases is terms implied for business efficacy. In Australia, the conditions necessary to found the implication of a term for business efficacy in any contract traverses welltrodden ground. These were stated by the Privy Council in BP Refinery (Westernport) Pty Ltd v Hastings Shire Council ${ }^{22}$ as being that the term to be implied must:

- be reasonable and equitable;

- be necessary to give business efficacy to the contract so that no term will be implied if the contract is effective without it;

- be so obvious that "it goes without saying";

- be capable of clear expression; and

- not contradict any express term of the contract. ${ }^{23}$

These principles have been repeated by the High Court of Australia on other occasions. ${ }^{24}$ A similar test has been applied in England where it has generally been held that it is not enough for a court to say that a suggested implied term is reasonable or that the presence of that clause would make the contract better or fairer, it is essential that the insertion of a term is necessary to give the contract "business efficacy" and one that 'reasonable men would have agreed without hesitation to its insertion'. ${ }^{25}$ There are no instances of a court implying any term into a lease on the basis of business efficacy. In contrast, terms have been implied at law in relation to the use of common areas (under the control of the landlord) on the basis of the rule in Wheeldon $\mathrm{v}$ Burrows. ${ }^{26}$ This rule provides that rights in the nature of a quasieasement could be implied in the circumstances where they were "continuous and apparent" and were needed or required for "the reasonable enjoyment of the property granted'. ${ }^{27}$ Thus, in Wilcox $v$ Richardson ${ }^{28}$ a lessee was granted implied "ancillary" rights to use common property under the control of the landlord outside the leased area to conduct a fish shop so that he could take full benefit of the grant made by the lease. This decision was applied in similar circumstances in Nguyen $v$ Perri $^{29}$ where terms were not implied 'ad hoc ...for business efficacy' but by an interpretation of the express terms of the lease and subjecting them to the above rule. $^{30}$

One reason for not implying a term into a commercial lease on the basis of the business efficacy test may be the fact that given the complex and comprehensive

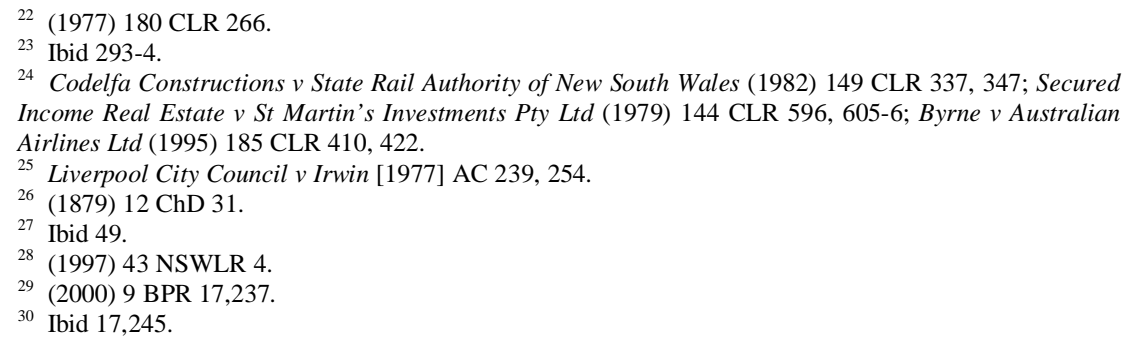


nature of the terms of most commercial leases there is less ground for supposing that the parties have failed to address the question at the time of contract. ${ }^{31}$

Unsurprisingly therefore, the implication of an obligation to repair on the part of the landlord on the basis of business efficacy has received little support judicially. The apparent reason being that a covenant to repair on the part of the landlord is not a covenant that is so obvious it goes without saying and therefore fails the five point test. The circumstances in which a covenant to repair on the part of the landlord has been implied are interestingly limited to the repair of common areas within multi tenant buildings and has been implied as a matter of law and not fact. When the authorities in which a covenant to repair has been implied are examined closely however, it is apparent that some of the judges may have been prepared to imply the covenant in either law or fact. The difficulty in drawing a distinct line between fact and law is highlighted most recently by Finn $\mathrm{J}$ in Hughes Aircraft Systems International $v$ Airservices Australia. ${ }^{32}$ His Honour was prepared to imply a term on the basis of business efficacy and as a matter of law into the particular type of contract. The same overlap is evident in the leasing authorities which have implied an obligation upon the landlord to repair common areas. ${ }^{33}$ Do the same imperatives exist for implying a covenant to repair in stand alone commercial buildings?

\section{THE CASE FOR a COVEnANT to Repair IMPLIED AT LAW}

Given the judicial reluctance to imply terms into leases as a question of fact and keeping in mind the new found judicial willingness to consider the implication of an obligation of good faith into leases as a matter of law, ${ }^{34}$ can an obligation on the part of a commercial landlord to take responsibility for repair excluded from the tenant's covenant be implied at law? A term may be implied as a matter of law where it is 'a legal incident of a particular class of contract'. ${ }^{35}$ Although there is disagreement over the exact considerations a court will take into account when determining in the first instance whether a term should be implied, a significant number of authorities accept that 'necessity' is a key element. The statement of Bowen LJ in Miller $v$ Hancock, that the term should be one which 'the parties ... must have intended by necessary implication, as a basis without which the whole transaction would be futile' has been adopted in the context of leases. ${ }^{36}$ In the

\footnotetext{
31 Codelfa Construction Pty Ltd v State Rail Authority of New South Wales (1982) 149 CLR 337.

32 (1997) 146 ALR 1 (implied term of good faith in a tender arrangement).

33 Refer to Liverpool City Council v Irwin [1977] AC 239.

${ }^{34}$ Softplay Pty Ltd v Perpetual Trustees (WA) Pty Ltd [2002] NSWSC 1059; Barrett J said that 'the implied term would have the capacity to bolster significantly the arguments based on the covenant for quiet enjoyment and derogation from the grant'. ([9])

${ }^{35}$ Codelfa Constructions Pty Ltd v State Rail Authority of NSW (1982) 149 CLR 337, 345; Byrne v Australian Airlines Ltd (1995) 131 ALR 422, 426, adopting the view of English Courts in Lister $v$ Romford Ice \& Cold Storage Co Ltd [1957] AC 555 and Liverpool City Council v Irwin [1977] AC 239; Scally v Southern Health and Social Services Board [1992] 1 AC 294.

36 (1893) 2 QB 177, 180.
} 
broader Australian context, explanation of the concept of necessity has been given by McHugh and Gummow JJ in Byrne $v$ Australian Airlines Ltd ${ }^{37}$ where their Honours noted that:

Many of the terms now said to be implied by law in various categories of case reflect the concern of the courts that, unless such a term be implied, the enjoyment of the rights conferred by the contract would or could be rendered nugatory, worthless, or, perhaps, be seriously undermined. Hence, the reference in the decisions to "necessity" ... This notion of "necessity" has been crucial in the modern cases in which the courts have implied for the first time a new term as a matter of law. ${ }^{38}$

In the context of repair, the question for a court is, therefore, will the demise to the lessee be rendered useless or be seriously undermined if an obligation to repair the premises is not imposed on every lessor of a commercial building? It is apparent from the authorities that the implication of a repair obligation on the part of the lessor in such wide terms in all leases will not be accepted. The limited class of leases of multi tenanted buildings where the landlord retains occupation of common facilities has received a favourable response. For example, in Cockburn v Smith, ${ }^{39}$ the owner of a block of flats let one of the top flats but kept the roof of the building and guttering in his own possession and control. The guttering became defective; water escaped and caused damage to the inside of the tenancy. The Court found that as the landlord had retained control of the guttering, although there was no express repair covenant on the part of the landlord, the landlord was under an obligation to remedy any defects of which the landlord had notice and which were a source of damage. However, Bankes LJ, in dictum, made the following further comment:

I want to make it plain at the outset that this is not a letting of a whole house, where, without an express covenant or a statutory obligation to repair, the landlords would clearly be under no liability to repair any part of the demised premises whether the required repairs were structural or internal and whether or not they had notice of the want of repair. ${ }^{40}$

In a similar vein, the House of Lords in Liverpool City Council v Irwin ${ }^{41}$ implied a covenant to repair upon the landlord of a multi-story building containing a number of tenancies for the landlord to keep various common areas in a proper state of repair. There was no express covenant on the part of the landlord in any of the leases. Lord Wilberforce in applying the test of necessity to the lease of a mutli tenanted building stated in relation to the stairs, lift and the rubbish chutes that:

\footnotetext{
37 (1995) 131 ALR 422.

38 Ibid 450

39 [1924] 2 KB 119.

40 Ibid 128.

41 [1977] AC 239.
} 
They are essentials of the tenancy without which life in the dwellings, as a tenant, is not possible. To leave the landlord free of contractual obligation as regards these matters, and subject only to administrative or political pressure, is, in my opinion, totally inconsistent with the nature of this relationship. The subject matter of the lease (high-rise blocks) and the relationship created by the tenancy demands, of its nature, some contractual obligation on the landlord. ${ }^{42}$

Certainly, in this instance, the fact that the courts were dealing with a multitenanted property under a common landlord rather than a single stand alone property with a landlord and one tenant was of significant relevance. It could hardly be practically or legally efficacious for individual tenants upon their own initiative to undertake repairs of common areas and the general structure of a building housing a number of tenants. $^{43}$

However, the situation where there is a lease of a stand-alone structure and the tenant has the express obligation to repair and there is nothing express concerning any landlord's obligation to repair appears to be treated differently by the courts. In the first instance, it would seem that subject to the rules relating to the construction of such a covenant, the tenant would have the entire obligation to repair. The rules relating to repair limit the amount and type of repair for which a tenant may be liable and does not involve giving back to the landlord something wholly different from that which the landlord leased. ${ }^{44}$ That aside, particular difficulties arise in the interpretation of the repair obligations under a lease where the tenant has the only express obligation to repair but this express obligation is subject to exceptions such as fair wear and tear or, just as commonly, structural repairs.

The question then arises as to who bears the liability for the repairs to the items covered by those exceptions. As discussed above there is little judicial support for the implication of a covenant at law on the part of the landlord to repair the demised premises. The argument that the lease is rendered useless or seriously undermined unless the lessor is obliged to maintain the structural aspects of the building is less convincing where the lessee is in control of the whole of the building. Other considerations of policy and reasonableness also impact such as the commercial nature of the relationship, the usual existence of an express term that no warranty of fitness for the purpose is given by the lessor and the fact the use of the whole of the premises is largely within the control of the lessee. Despite these factors, is it the case that tenants and landlords, by exempting certain obligations of repair from commercial leases assume the responsibility for these repairs will lie with the landlord?

\footnotetext{
42 Ibid 254.

${ }^{43}$ Refer also to Miller v Hancock [1893] 2 QB 177, 180-1; De Meza v Ve-Ri-Best Manufacturing Co Ltd (1952) 160 Estates Gazette 364, CA; Penn v Gatenex Co Ltd [1958] 1 All ER 712, 720.

${ }^{44}$ Graham v Markets Hotel Pty Ltd (1943) 67 CLR 567, 580-1 (Latham CJ).
} 


\section{JUDICIAL ASSUMPTIONS OF LANDLORD RESPONSIBILITY FOR REPAIR}

Generations of lease interpreters, from practitioners to the judiciary, have assumed that where a tenant has an express obligation to repair premises with exemptions expressed, that those matters listed in the exemptions would be the responsibility of the landlord (or the subject of insurance where appropriate) should that exemption describe the nature or cause of the disrepair. Common examples include both structural disrepair and disrepair caused as a result of fair wear and tear.

For example, in Regis Property Co Ltd v Dudley ${ }^{45}$ a tenant had an express obligation to keep a flat 'in good and substantial repair and clean and sanitary condition (fair wear and tear and damage by accidental fire excepted)'. In interpreting this clause with a view to setting adjustments to rent required by a statute affecting the tenancy, Lord Denning, in dictum, speaking of the fair wear and tear exception made the following observations

It follows that when a washer on a tap wears out and has to be remedied, or cistern has to be regulated, or radiator leaks, the tenant is not liable, because it is fair wear and tear. The defect must be made good by the landlord if he wants to get his full rent. It is part of the burden which falls on him. $^{46}$

There did not appear to be any express obligation on a landlord to undertake these sorts of repairs and the landlord's liability appeared to be assumed without argument. Likewise, in Reilly $v$ Liangis Investments Pty Ltd, ${ }^{47}$ a lease contained a provision which obligated the tenant to keep motel premises in repair but excluded structural repair. Justice Young, upon considering the substance of what was required to be done, determined that the repairs were not structural but said further, in dictum, that the 'wholeness of the building' was a matter for the landlord alone and that anything 'that interferes with the stability of the building which involved interference with structural members was something for the landlord'. ${ }^{48}$ There was no express clause imposing liability to repair upon the landlord in relation to any part of the building. Young $\mathbf{J}$ assumed the responsibility for structural repairs would fall upon the landlord because of the express exclusion of these repairs in the tenant's repair obligation.

It is suggested that these judicial utterances represent the conventional views of lawyers and tenants about the allocation of liability for repair where, despite the absence of an express positive obligation on the part of the landlord, certain repair items are excluded from the obligations of the tenant.

\footnotetext{
45 [1959] AC 370.

46 Ibid 411.

47 (2000) 9 BPR 17,509.

48 Ibid 17,514
} 


\section{Where the AsSUmption has not beEn MADE}

There are two decisions in Australia of recent vintage where the assumption was not made and where the court held that in the absence of an express obligation upon the landlord, the landlord would not be responsible for structural repair. The first is a decision of the Victorian Civil and Administrative Tribunal, Ali v Hazim. ${ }^{49}$ The authors recognise that this decision is not a binding authority, however, given that the lengthy reasons for the judgment squarely raise the central issue, the decision is worthy of consideration. Briefly, this case concerned the operation of a restaurant under a lease whereby the landlord made no warranty as to the suitability of the premises for use as a restaurant. The lease imposed no obligations on the landlord to carry out any repairs, but a clause expressly imposed the obligation to 'repair, clean and maintain' upon the tenant except for fair wear and tear. The lease expressly excused the tenant from 'carrying out structural repairs or making payments of a capital nature unless the need for them resulted from the negligence of the tenant or the tenant's employees, the failure of the tenant to perform its obligations under the lease or the tenant's use of the premises.'

Various disputes arose between the landlord and tenant about which it is unnecessary to refer to in detail here. Arising from these disputes, the tenant sought reimbursement from the landlord costs associated with rectification of safety and structural deficiencies and, in doing so, sought to impose upon the landlord an implied term, arising from the construction of the lease, that the landlord was responsible for structural repairs. Counsel for the tenant argued that, as the tenant was expressly exempted from carrying out structural repairs or capital improvements, the clear implication was that these were the responsibility of the landlord, notwithstanding the lack of any express obligation upon the landlord so to do. In making this submission, the tenant relied upon the principle adumbrated in Barrett $v$ Lounova (1982) $L t d .{ }^{50}$ In holding that the landlord had no obligation to undertake structural repairs in this particular case, MF Macnamara, Deputy President of the Tribunal, relevantly commented:

To consider a hypothetical lease in which there is simply no covenant to repair at all by either party, the non existence of such a covenant cannot be taken as implying that either landlord or tenant is contractually obliged to the other to carry out the necessary repairs. If a repair is necessary then either it will not be carried out at all or one party or the other party will, consulting its commercial interests, carry out the repair; but the existence of the impasse, namely, the need for repair which neither party is contractually obliged to undertake, does not imply an obligation upon either party to do it, so the absence of a covenant by the landlord to repair or to carry out

\footnotetext{
49 [2002] V Conv R 58-570.

50 [1990] 1 QB 348.
} 
any capital works and the existence of a covenant by the tenant to repair, but not to carry out the capital works simply means that neither party is obliged to carry out the capital works. ${ }^{51}$

Quite coincidentally, almost simultaneously, the Supreme Court of Victoria had occasion to consider the same question in the case of Carbure Pty Ltd v Brile Pty $L t d{ }^{52}$ Justice Balmford there also declined, in the circumstances, to follow Barrett $v$ Lounova (1982) Ltd and in a well reasoned judgment made a number of interesting observations concerning its limited application. The case concerned the possible implication of a covenant on the part of the landlord of a chalet, consisting of four buildings, in circumstances where there was a covenant on the part of the tenant to keep the premises 'cleaned, repaired and maintained' except for fair wear and tear but the lease expressly stated that the tenant was not responsible 'to repair or maintain the structure or spend money on items of a capital nature unless the repair, maintenance or expenditure became necessary because of the tenants' business or the tenants' failure to perform obligations under the lease' ${ }^{53}$ This covenant was in exactly the same terms as that in Ali v Hazim. ${ }^{54}$ The court satisfied itself that a situation could exist where neither landlord nor tenant might be responsible for the repair of the premises and the cost of maintaining and repairing them would be a matter of negotiation between themselves. In other words, the covenant to repair was not an essential term in a lease such as the covenants for quiet enjoyment and not to derogate from the grant which, would be implied if they were not express. Although the examples given related to residential accommodation, the same principles could apply to commercial leases. ${ }^{55}$

Justice Balmford then considered two Australian authorities relative to implied terms. ${ }^{56}$ In the first case a term was implied to maintain a lift service to demised premises, its discontinuation being a derogation from the grant, and in the second case, where the court failed to order a landlord to consent to repairs rather than carry them out. Both were of little assistance in the instant case. Balmford $\mathrm{J}$ then considered the effect of Barrett $v$ Lounova (1982) Ltd $^{57}$ and particularly noted its lukewarm reception in the United Kingdom. ${ }^{58}$ The only way in which his Honour considered the term could be implied in Australia was by applying the rules settled by the High Court in BP Refinery (Westernport) Pty Ltd v Hastings Shire Council ${ }^{59}$ already mentioned. When these rules were applied one-by-one to the particular situation, Balmford $\mathrm{J}$ did not consider, in this particular case, that the implication of

\footnotetext{
51 (2002) V Conv R 58-570, [15].

52 (2002) V Conv R 54-663.

${ }^{53}$ Ibid [7]

54 (2002) V Conv R 58-570.

55 For example, Southwark London Borough Council v Tanner [1999] 3 WLR 939, 952.

${ }^{56}$ Karagginas $v$ Malltown Pty Ltd (1979) 21 SASR 381; Advance Fitness Corporation Pty Ltd v Bondi Diggers Memorial \& Sporting Club Ltd [1999] NSW SC 264.

57 [1990] 1 QB 348.

58 See Adami v Lincoln Grange Management Ltd [1998] 17 EG 148.

${ }^{59}$ (1977) 180 CLR 266.
} 
a term against the landlord could be justified. His Honour listed the points which drew him to this conclusion as follows:

The general practice that a landlord is not responsible for repairs, but doubt as to whether the law of Victoria permits the implication of a term sought, the uncertainty as to whether such a term can be regarded as reasonable or equitable and whether it is necessary to give efficacy to the contract all militate against the implication of the term. ${ }^{60}$

It is interesting to note some evidentiary factors which influenced the court's decision. First, it appeared that the site upon which the chalet was constructed had potential as a development site and expenditure on structural repairs to such old buildings could not be economically justified. ${ }^{61}$ Secondly, the court rejected a submission on the part of the tenant which was based upon a duty of the landlord to take reasonable care to avoid foreseeable risk of injury which might have resulted as a consequence of disrepair. As his Honour said, a case of negligence was not before him and that 'the parameters of the duty of care would not, in any case, correspond with the terms of such a covenant'. ${ }^{2}$ Certainly, the property was capable of remaining leased, as it had been for some time without these structural repairs occurring. Although the court did not refer to Ali v Hazim, ${ }^{63}$ the result of the litigation, on identical covenants, was the same.

It is clear that the validity of the reasoning in these cases relies upon an adoption of the general principle that in the absence of a repair covenant there is no obligation to repair on either party. ${ }^{64}$ However, this ignores the fact many parties, in particular tenants, assume that if certain repair obligations are excluded from the tenant's obligations they will instead be borne by the landlord. This approach leads directly to the question of exactly what is the relevance of listing exemptions in the repair covenant.

\section{VIII}

\section{An Alternative Analysis - Correlative Obligations AS THE BASIS FOR IMPLICATION IN FACT}

A correlative obligation arises in a lease, most commonly, in circumstances where a tenant pays a certain sum as an outgoing for a stipulated reason without any corresponding express obligation in the lease on the part of the landlord to provide a specific service. The obligation on the part of the landlord to provide this service

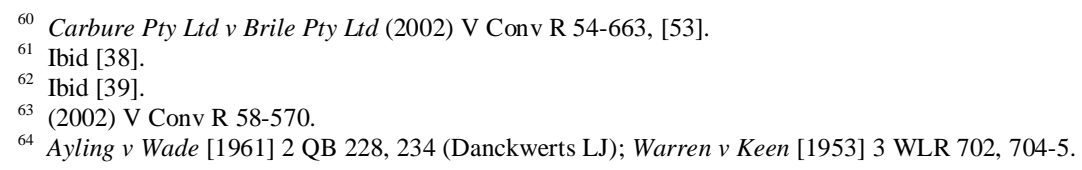


has been said to become a correlative obligation to that of the tenant to make the payment. For example, the responsibility of the landlord in Modbury Triangle Shopping Centre Pty Ltd $v$ Anzil ${ }^{65}$ to provide lighting in a car park to a tenant for extended hours was effectively correlative to the tenant's obligation to pay the costs of services in the common areas which included the cost of that lighting. Instruments of lease are notorious for incorporating express covenants on the part of the tenant to be read in conjunction with implied covenants on the part of the landlord. Business efficacy may only be one reason for the implication of a covenant against the landlord. There may be other reasons. In a similar vein, the express obligation upon a tenant to pay an amount equal to the yearly insurance premium for a policy in the name of the landlord effectively makes the tenant a co-insured who could force the landlord to spend the insurance money toward reinstatement of the property. ${ }^{66}$ Whilst it depends upon how one defines correlative rights, in the context of a particular lease, they are more than likely to be identified in circumstances where there is an obligation upon the tenant to pay a sum of money for a certain purpose but there is no corresponding express obligation upon the landlord to engage in any activity to fulfil that purpose. They are rarely found where there is no payment of money, one express on the part of the tenant and a complementary obligation implied on the part of the landlord. It is for this particular reason that the case of Barrett $v$ Lounova (1982) Ltd $^{67}$ is particularly interesting in that it involves an express covenant to repair on the part of the tenant and an implication of a covenant on the part of the landlord, not any obligation by the tenant to pay an outgoing.

The question of a correlative obligation in a lease appears to have arisen first in the case of Barnes $v$ City of London Real Property Company. ${ }^{68}$ In that case, all tenants were charged rent for sets of rooms used as offices in a commercial building at a certain yearly rate with additional rent being charged 'for cleaning of the rooms by a resident housekeeper appointed for the time being by the landlord'. Upon a transfer of the reversion, the transferee set up similar arrangements stating expressly that 'such appointment shall not constitute any responsibility on the landlord's part for any act or deficiency of such housekeeper.' The housekeeper without notice left the building and another non-resident housekeeper was appointed who attended at irregular hours. With all tenants paying additional rent to the landlord for the purpose of payment of a housekeeper on a more regular basis, the question arose, that in the absence of an express covenant on the part of the landlord to supply these services, was there an implied covenant so to do which obligation corresponded with the tenants' obligation to pay additional rent for those services. On this point, Sargent J made the following observation:

... I should certainly feel inclined to come to the conclusion that a correlative obligation was implied by the lessors corresponding with the obligation on the part of the tenants to pay the rent for the particular service.

\footnotetext{
65 (2000) 205 CLR 254.

${ }^{66}$ Mumford Hotels Ltd $v$ Wheler [1964] Ch 117, 127.

${ }^{67}$ [1990] 1 QB 348.

${ }^{68}$ [1918] 2 Ch 18.
} 
There are many cases in which, where expression is defective, the court has nevertheless implied an obligation on the part of the person on whom the obligation was not in terms imposed... Mr Grant (counsel for the landlord) in his argument was almost bound to confess that, if there were a reservation of rent in favour of a lessor for the purpose of effecting insurance against fire on the property, there must in that event be an obligation on his part to employ the money paid to him for insurance in effecting that insurance. $^{69}$

The court thus found that these agreements imposed upon the landlord an obligation, corresponding to the obligation imposed on the tenants, to pay them rent for the purpose of a particular service and the landlord could not take or retain the additional rent without performing the service. This obligation not being expressed was implied. The correlative obligation in this case arose through an obligation of the tenant to pay a certain sum for a specific purpose stated in the lease such sum to be defrayed only for that purpose under the control of the landlord.

However, in Barrett $v$ Lounova (1982) $L t d{ }^{70}$ the principles relating to correlative obligations in leases were applied for the purpose of implying a covenant to repair. In that case, the tenancy of a dwelling house was granted in 1941 for one year and thereafter from month to month. The tenant had covenanted to undertake 'all inside repairs ... and to permit the landlord and his agents to enter at all reasonable times and for all reasonable purposes'. ${ }^{71}$ The agreement was silent about external and structural repairs. Some 44 years later, the premises had fallen into serious disrepair. The tenant brought an action claiming that the landlord was in breach of an implied covenant to carry out external and structural repairs and sought damages and specific performance against the landlord. The Court of Appeal, with some hesitation, applying the ordinary principles of contractual construction concerning the implication of terms, implied an obligation upon the landlord to undertake external repairs notwithstanding there was no express obligation in the lease. Kerr $\mathrm{LJ}$ made the decision reluctantly upon the basis that the implied obligation on the landlord was one which was correlative to the express covenant by the tenant to keep the inside and fixtures in good repair. ${ }^{72}$ Several reasons for this decision commended themselves to the court. First, the covenant imposed on a tenant in respect of the repair of the inside could no longer have been complied with unless the exterior had been kept in repair. Secondly, the covenant imposed on the tenant was intended to be enforceable throughout the tenancy which, by that stage, had been in effect for 46 years.

Kerr LJ concluded that it was necessary, as a matter of business efficacy 'to make the agreement workable' that an obligation to keep the exterior in repair must be

\footnotetext{
69 Ibid 32.

${ }^{70}$ [1990] 1 QB 348.

71 Ibid 353.

72 Ibid 358.
} 
imposed on someone. ${ }^{73}$ His Lordship rejected the notion that the tenant was obliged to keep the outside in repair as well as the inside to such an extent as would be necessary to enable the inside to be repaired. He described this as 'un-business like and unrealistic'. ${ }^{74}$ Secondly, he said that as the tenancy had reverted to a monthly tenancy some 40 years earlier it was "clearly unrealistic to conclude that this could have been the common intention' ${ }^{75}$ Finally, Kerr LJ found that there was clearly an obligation on the tenant to keep the inside in repair and that it would be wrong, 'as a matter of elementary construction' to imply an obligation upon the tenant relating to the repair of the outside as well. ${ }^{76}$

Kerr LJ also refused to imply a joint obligation upon both parties to keep the exterior in repair and preferred the third solution which to him 'made business sense, ${ }^{77}$ by imposing an obligation on the landlord.

In effect, the case revolved around the courts' interpretation of the business efficacy rule.

\section{iX Criticisms of the Correlative Obligation Approach}

The decision of Barrett $v$ Lounova (1982) Ltd has not received a warm reception in either the United Kingdom or Australia and has been distinguished generally on its particular facts. For example, in Adami v Lincoln Grange Management Ltd, ${ }^{78}$ a covenant from the landlord to keep the structure in good repair was not implied in circumstances where the landlord had taken over the insurance of a three storey block of flats, the numerous leases of which contained covenants by the tenants to keep the demised premises in repair and to maintain insurance against specified losses or damage. The landlord itself actually insured the buildings under a block policy which included subsidence damage. A claim was made on this policy following subsidence damage which included damage to the particular tenant's maisonette.

The landlord sought indemnities from all tenants to carry out remedial work beyond that which was covered by the insurance as the insurers were experiencing financial difficulties. All tenants, other than the tenant in question, gave indemnities but the tenant in question carried out the work himself. He sought recovery of the cost of that work from the landlord alleging an implied covenant by the landlord to repair the structure. There was clearly damage caused by the subsidence to the structure which was caused from the insured risk. The limit of the landlord's obligation

\footnotetext{
73 Ibid.

74 Ibid.

75 Ibid.

76 Ibid.

77 [1990] 1 QB 348, 359.

78 [1998] 17 EG 148.
} 
found to be implied was to simply lay out insurance monies to make good that damage. Having done that, there was no other ground for importing a further obligation to carry out works of repairs not covered by that policy. There was an express clause in the lease requiring the tenants to co-operate with the landlord and other tenants in carrying out repairs to the block if they became necessary.

However, the court refused to enlarge this covenant to an implied covenant on the part of the landlord to repair. Even more relevant, the court suggested that the cases giving rise to a "correlative obligation" or cases where there was an obligation to carry out work only appeared to come into effect where there was an obligation by a tenant to pay a fixed sum towards the cost of doing work. This was not the case here. Although it was acknowledged that Barrett $v$ Lounova ${ }^{79}$ was binding on the court, it was distinguished on its special facts.

Thus, there seems to be little enthusiasm in Australia and the United Kingdom to import a correlative obligation on the part of the landlord in relation to the covenant to repair where there is no express obligation upon the landlord so to do.

\section{A Further Alternative: Can the Landlord's Failure to RepaIR CONSTITUTE A BREACH OF THE COVENANT FOR QUIET ENJOYMENT?}

A covenant for quiet enjoyment on the part of the landlord is found in every lease. If it were not expressed, it would be implied as a matter of law arising from the creation of the relationship of landlord and tenant. ${ }^{80}$ As a general rule, the covenant for quiet enjoyment operates to secure to the tenant the enjoyment of the premises for all usual purposes. However, the landlord would only be responsible for loss suffered by a tenant if an act or omission of the landlord was shown to be a breach of that covenant. ${ }^{81}$ Certainly, there are cases of lessor liability for repair being implied in the absence of an express covenant, but these have generally concerned situations where the landlord has been the common lessor of a number of tenancies in a multi-tenanted building and the landlord has failed to ensure that an area of the building under the landlord's control, such as the roof, has remained in good repair. Specifically, the cases refer to the instances of water damage to a tenant's property in demised premises caused by a failure of the landlord, through negligence, to ensure that a roof or a container holding water on common property is water tight. ${ }^{82}$ Martin's Camera Corner Pty Ltd v Hotel Mayfair Ltd ${ }^{83}$ is a recent iteration of this principle where the landlord had no express obligation to repair and liability was imposed through a breach of the covenant for quiet enjoyment.

\footnotetext{
79 [1990] 1 QB 348.

${ }^{80}$ Budd-Scott v Daniel [1902] 2 KB 351, 356.

${ }^{81}$ Martin's Camera Corner Pty Ltd v Hotel Mayfair Ltd [1976] 2 NSWLR 15, 23 (Yeldham J).

${ }^{82}$ Anderson v Oppenheimer (1880) 5 QBD 602; Booth v Thomas [1926] Ch 397, 402-3.

${ }^{83}$ [1976] 2 NSWLR 15.
} 
In Hargroves, Aronson \& Co v Hartopp,${ }^{84}$ Lord Alverstone CJ conceded, in similar circumstances to those above, that whilst no covenant to repair could be implied against a landlord in respect of those parts of the premises leased to the tenant, it would be implied in respect of other parts of the premises. However, liability imposed upon the landlord because of disrepair, not the express obligation of the tenant to address, has been imposed through the covenant for quiet enjoyment largely in multi-tenanted buildings rather than in stand alone properties. Yeldham $\mathbf{J}$ in Martin's Camera Corner Pty Ltd v Hotel Mayfair Ltd ${ }^{85}$ clearly equated loss by the tenant through the negligence of the landlord in maintaining the fabric and structure of a multi tenanted property with the type of loss caused through breach of the covenant for quiet enjoyment.

This argument was run unsuccessfully for the tenant in $R \& A$ Becker Pty Ltd $v$ Cariste Pty $L_{t d}{ }^{86}$ where the court had to determine whether the landlord or tenant bore the responsibility to repair underground fuel tanks pursuant to the lease of a service station. The service station was located in a shopping centre and the fuel tanks supplying fuel to the station were located outside the leased premises. The tenant's complaint was that the fuel was being contaminated by water. The tenant paid for the repair of the pipes so that they could operate their business and sought reimbursement from the landlord who disclaimed liability under the lease. Nothing in the lease clearly allocated responsibility for the repair of the tanks to either party. Austin $\mathbf{J}$ found that, as nothing in the lease expressly imposed an obligation upon the landlord to repair the pipes, failure to repair them could not constitute a breach of the covenant for quiet enjoyment by the landlord. ${ }^{87}$ The tenant countered this by submitting that notwithstanding the pipes were not part of the premises, the failure of the landlord amounted to a breach of the covenant for quiet enjoyment as it impacted significantly upon the ability of the tenant to carry on the very business that was permitted (and obliged) to carry on under the lease. Austin $\mathrm{J}$ answered this by stating:

While accepting that an omission can constitute a breach of that covenant, [quiet enjoyment] I reject the submission that the covenant implied an obligation on the defendant to repair any of the pipelines. Arguably, in the circumstances, the covenant for quiet enjoyment implied an obligation upon the [landlord] to allow the [tenant] reasonable access for the repair of the pipes since the use of the pipes are necessary for the conduct of the [tenant's] business, but it does not follow that the [landlord] impliedly undertook an obligation through the covenant for quiet enjoyment, to carry out the repairs itself. ${ }^{88}$

\footnotetext{
84 [1905] 1 KB 472.

85 [1976] 2 NSWLR 15.

86 (2001) 11 BPR 20,111.

87 Ibid 20,117 .

88 Ibid. See also Westpac Merchant Finance Ltd v Winstone Industries Ltd [1993] 2 NZLR 247, 253

(lessor had express obligation to repair exterior of premises but not defective pipe. Held: failure to repair
} 
That said the actual decision was ultimately based upon an interpretation of a definition in the lease which Austin J said indicated that the repairs were the tenant's responsibility. However, his Honour's reasoning in relation to the linkage between the covenant to repair and the covenant for quiet enjoyment is of interest, but given the final result not conclusive of a linkage.

\section{CONCLUSIONS}

There are a great many commercial leases in which there are express covenants requiring the tenant to keep and maintain the repair of demised premises. More often than not, these same leases do not include an express obligation on the part of the landlord to undertake any repair, but purport to exclude certain items of repair from the tenant's repair obligations. Given the assumptions of responsibility made by esteemed members of the judiciary and a significant number of practising lawyers should this "common understanding ${ }^{89}$ be imported into all commercial lease transactions? As the path to recognition of such an obligation on the part of the landlord has already been trodden in relation to multi-tenanted buildings, the question arises as to whether policy requires the recognition of such an obligation in all commercial leases.

If such a term is not implied the question must inevitably arise as to the effect of making a tenant liable to repair and then excluding some particular types of repairs, most commonly, structural repairs and fair wear and tear. It is one thing to say that a tenant is under no express obligation to undertake a structural repair in the event that it is necessary, but it seems quite another thing to say that no one is really responsible for the repair, and if the structure requires repair, it is a matter to be negotiated between the parties or paid for by the tenant if the tenant wishes to remain in the premises. However, where a party to a lease carries out work where neither party are under an obligation to do so, there is no right of recoupment from the other party. This is the case even where the landlord benefits significantly from work carried out by a tenant..$^{90}$

There is also the question raised by counsel for the tenant in Carbure Pty Ltd $v$ Brile Pty Ltd, ${ }^{91}$ but dismissed by the court, of a tenant, in control of the premises being liable for personal injury which might occur as a result of disrepair. As Balmford J said, 'the parameters of the duty of care would not, in any case, correspond with the terms of such a covenant'. ${ }^{92}$ That sentiment may well be right, but it

pipe resulting in loss of water by tenant was a breach of the covenant for quiet enjoyment as there was an obligation under that clause to maintain water supply to the premises).

${ }^{89}$ Byrne v Australian Airlines Ltd (1995) 185 CLR 410, 449.

90 Batiste v Lenin (2002)11 BPR 20,403, 20,416 (Sheller JA).

91 (2002) V Conv R 54-663.

92 Carbure Pty Ltd v Brile Pty Ltd (2002) V Conv R 54-663, [39]. 
is likely to be a tenant who bears the burden of significant repair where premises do not comply with other statutes, for example relating to workplace health and safety, or some particular industry standard, notwithstanding there is an exemption in the lease in relation to the type of repair required in that instance.

The other curiosity is really to do with the drafting of the clause. There would appear no real reason for an exemption to be contained in a lease in many cases. It would be sufficient simply to expressly oblige the tenant to undertake all repairs, as the exemption is easily rendered meaningless. However, that is not to say that in all cases the results would be similar to the above Australian decisions. In both cases, the court was very careful to apply the rules relating to the implication of terms in contracts and not to completely deny the possibility that, in different circumstances, a repair covenant might be implied against the landlord.

The notion of the correlative obligation does not seem to have found favour in any jurisdiction as a means of implying a repair covenant. From the point of view of identifying obligations, the formulation in Barrett $v$ Lounova (1982) Ltd $^{93}$ relating to implied obligations may appear to be rational in the sense that it might be pointless to enforce a covenant where the enforcement of that covenant would be of no effect because someone else, viz, the landlord first had to do something or, put in another way, discharge an implied obligation. The factors influencing a court's decision would doubtless be, in the first instance, the construction of the lease, but if the cases are read closely, the nature of the premises, the expectation of the parties at the time the lease may have been entered into, whether or not the lease could be satisfactorily performed on either side without the implication length of the lease and nature of the tenancy would all be factors. These variables alone make it difficult to give predictable legal advice where the occasion arises. Generally, it must be said that there are probably stronger views against the implication of covenant to repair and this might initially be a guiding principle. Although a tenant may be expressly exempted from an obligation to undertake a certain type of repair, if the landlord has no express or implied obligation to fill the gap, then the liability to repair will fall upon the tenant where the issue arises during the currency of the lease. It is submitted that a significant number of commercial tenants would be oblivious to this unspoken liability.

An obligation to undertake repair on the part of the landlord may be implied where the breach complained of by the tenant can also be characterised as a breach of the covenant for quiet enjoyment. This is likely to occur, subject to the express terms of any lease which may negate the possibility expressly, and dependant upon the particular complaint. Where the want of repair significantly contributes to the difficulty or makes it impossible for the tenant to conduct their business in the premises, then the case based upon a breach of the covenant for quiet enjoyment is strengthened.

\footnotetext{
${ }^{93}[1990] 1$ QB 348
} 
Finally, and most tellingly, where there is doubt as to any obligations in a lease, express words should be used to clearly delineate the structural repair obligation in a positive manner and not merely leave it as an exemption form repair obligation on the part of the tenant. Otherwise, the exemption may be illusory. The authorities certainly raise very real issues which are common place particularly when it is noted that the two Australian cases Ali v Hazim ${ }^{94}$ and Carbure Pty Ltd v Brile Pty $L t d^{95}$ were cases dealing with clause in the Standard Law Institute in Victoria lease agreement.

${ }_{94}$ (2002) V Conv R 58-570.

${ }^{95}$ (2002) V Conv R 54-663. 